\title{
Effect of Salinity Stress on Antioxidant Defense System of Niger (Guizotia abyssinica Cass.)
}

\author{
Hemla Naik Kavya Naik, Varadahalli R. Devaraj* \\ Department of Biochemistry, Bangalore University, Bengaluru, India \\ Email: *devaraj@bub.ernet.in
}

Received 23 March 2016; accepted 26 April 2016; published 29 April 2016

Copyright @ 2016 by authors and Scientific Research Publishing Inc.

This work is licensed under the Creative Commons Attribution International License (CC BY). http://creativecommons.org/licenses/by/4.0/

(c) (;) Open Access

\section{Abstract}

Salinity is one of the principal abiotic stresses that affect plant productivity by inducing osmotic stress, which in turn, causes oxidative stress. Plants respond to this oxidative stress by adjusting levels of antioxidants and associated components. 10-day old seedlings of Niger were evaluated for abiotic stress response in terms of antioxidants and antioxidant enzymes over $72 \mathrm{~h}$ in presence of up to $500 \mathrm{mM} \mathrm{NaCl}$ in combination with $\mathrm{CaCl}_{2}$. Stress markers: $\mathrm{H}_{2} \mathrm{O}_{2}$, lipid peroxidation, antioxidants; ASC and GSH and antioxidant enzymes such as POX, APX and GR were significantly elevated, while CAT was reduced. The response was concentration and time-dependent up to $300 \mathrm{mM} \mathrm{NaCl}$ and fluctuated beyond. Metabolic enzymes $\beta$-amylase and acid phosphatase exhibited moderate increase relative to controls. The parameters indicated tolerance of the plants to salinity up to 300 mM over $48 \mathrm{~h}$.

\section{Keywords}

Niger, Guizotia abyssinica, Salinity Stress, Antioxidants, Antioxidant Enzymes, Lipid Peroxidation

\section{Introduction}

Worldwide, $20 \%$ of total cultivated and 33\% of irrigated agricultural lands are exacerbated by high salinity. Phenomena like low precipitation, high surface evaporation, irrigation with saline water, weathering of native rocks, and poor agricultural practices have increased the rate of soil salinization to $10 \%$ per annum. It has been predicted that more than $50 \%$ of the arable land would be salinized by the year 2050 [1]. Soil salinization can be defined as the electrical conductivity (EC) of the saturation extract (ECe) in the root zone that exceeds $4 \mathrm{dS} \cdot \mathrm{m}^{-1}$

"Corresponding author. 
( $40 \mathrm{mM} \mathrm{NaCl})$ at $25^{\circ} \mathrm{C}$ and has exchangeable sodium of $15 \%$ [2].

High salinity may cause morphological and physiological changes which include ion toxicity, osmotic stress, nutrient deficiency and oxidative stress, ultimately leading to loss in crop yield [3]. Ion toxicity results are due to replacement of $\mathrm{K}^{+}$with $\mathrm{Na}^{+}$ions and interaction of $\mathrm{Na}^{+}$and $\mathrm{Cl}^{-}$ions with proteins and amino acids. While significant changes in water potential due to applied stress can lead to osmotic stress, decreased levels of photosynthesis can lead to nutrient deficiency [4]. Reactive oxygen species (ROS) generated under oxidative stress at dangerous levels are detrimental to cellular components, like membrane lipids, proteins, and nucleic acids [5]. A number of plant species have evolved antioxidant defense mechanisms to combat the devastating effects of oxidative stress. The ability to tolerate salinity by plants is often related to qualitative and quantitative changes in antioxidant systems. ROS defense mechanism encompasses enzymatic and non-enzymatic components. Enzymatic ROS-scavenging system includes peroxidases (POX), catalase (CAT), superoxide dismutase (SOD), and glutathione reductase (GR), while the non-enzymatic components include ascorbic acid (ASC) and reduced glutathione (GSH). Elevated levels of $\mathrm{H}_{2} \mathrm{O}_{2}$ and malondialdehyde (MDA) reflect altered balance in ROS production and detoxification. Salinity induced osmotic stress is also countered by plants through metabolic adjustments, such as synthesis of osmoprotectant like proline [6].

Niger (Guizotia abyssinica Cass.) crop is cultivated throughout India, East Africa and West Indies. The crop accounting for 3\% of Indian oil seed production belongs to family Asteraceae and tribe Heliantheae. Niger seeds contain around $30 \%-50 \%$ oil and about $20 \%$ protein. Oil is mainly used for culinary purposes, manufacture of cosmetics, soaps, paints, lighting and lubrication. Niger seed is exported as a bird feed and earning precious foreign exchange to the country. Currently, it is extensively studied as a potent source of biofuel [7]. The plant thrives under drought and poor soil conditions. Effects of salinity on germination and growth using in-vitro selection techniques have been reported [8]. The results of the investigation carried out to ascertain the biochemical and physiological changes as markers of abiotic stress tolerance/susceptibility are reported here under.

\section{Materials and Methods}

\subsection{Plant Material and Growth Conditions}

Niger seeds RCR-18 variety was procured from University of Agricultural sciences Dharward. Seeds were surface sterilized with $0.1 \%(\mathrm{w} / \mathrm{v})$ mercuric chloride for $1 \mathrm{~min}$, followed by three rinses in sterile distilled water. The seeds were sown in trays containing cocopith and acid-washed sand $(1: 1 \mathrm{w} / \mathrm{w})$ and watered twice a day with distilled water. The germination was carried out under natural greenhouse conditions; day/night temperature and relative humidity were $30 / 25^{\circ} \mathrm{C}$ and $75 / 70 \%$, respectively. The average photoperiod was $12 \mathrm{~h}$ light/12 h dark.

\subsection{Salt Stress Treatment}

10 days old seedlings of uniform size were randomly selected and gently uprooted to transfer them to a hydroponic system of half strength Hoagland medium [9] containing different concentrations of $\mathrm{NaCl}$ in combination with half strength $\mathrm{CaCl}_{2}$. Leaf samples were collected at 24,48 and $72 \mathrm{~h}$ and assayed for various parameters. Plants grown on Hoagland medium without $\mathrm{NaCl}$ served as control.

The experimental design used was random factorial scheme, with 3 evaluation points $(24,48,72 \mathrm{~h})$ and 6 media regimes (control, 100, 200, 300, 400, $500 \mathrm{mM} \mathrm{NaCl).} \mathrm{Each} \mathrm{experiment} \mathrm{was} \mathrm{done} \mathrm{in} \mathrm{triplicate.}$

\section{Determination of Relative Water Content (RWC)}

Leaf discs of $6 \mathrm{~mm}$ diameter were weighed to determine the fresh weight $(\mathrm{FW})$, soaked in distilled water at $25^{\circ} \mathrm{C}$ for $4 \mathrm{~h}$ to determine the turgid weight (TW), then oven dried at $80^{\circ} \mathrm{C}$ for $24 \mathrm{~h}$ to determine the dry weight (DW). The relative water content was determined by following the method of Turner and Kramer (1980) [10], using the equation: RWC $=(F W-D W) \times 100 /(T W-D W)$.

\section{Determination of Antioxidants}

\subsection{Ascorbic Acid (ASC)}

Ascorbic acid was estimated according to Sadasivam and Manickam (1997) [11]. The tissue was homogenized with $4 \%$ oxalic acid and subjected to centrifugation at 10,000×g for $10 \mathrm{~min}$. The reaction mixture consisted of 
$0.1 \mathrm{ml}$ of brominated sample extract made up with distilled water to $3.0 \mathrm{ml}, 1.0 \mathrm{ml}$ of $2 \%$ DNPH reagent along with 1 - 2 drops of thiourea. Post-incubation at $37^{\circ} \mathrm{C}$ for $3 \mathrm{~h}$, the orange-red osazone crystals formed were dissolved by adding $7.0 \mathrm{ml}$ of $80 \%$ sulphuric acid and absorbance was read at $540 \mathrm{~nm}$.

\subsection{Glutathione (GSH)}

GSH estimation was carried out according to the procedure of Beutler (1963) [12]. The tissue was homogenized in 3\% metaphosphoric acid. To the supernatant obtained after centrifugation DTNB [5, 5'-dithiobis (2-nitrobenzoic acid)] was added. Total glutathione concentration was estimated by monitoring the formation of 5-thio2-nitrobenzoic acid, which is proportional to GSH at $412 \mathrm{~nm}$ against reagent controls.

\section{Determination of Stress Response Factors}

\subsection{Hydrogen Peroxide $\left(\mathrm{H}_{2} \mathrm{O}_{2}\right)$}

Hydrogen peroxide content in Niger was estimated according to Velikova et al. (2000) [13]. Leaf tissues of control and stressed seedlings (500 mg) were ground in $5 \mathrm{ml}$ of $0.1 \%(\mathrm{w} / \mathrm{v})$ trichloroacetic acid in an ice bath. The homogenate was centrifuged at $10,000 \times \mathrm{g}$ for $15 \mathrm{~min} .0 .5 \mathrm{ml}$ of the supernatant was made up to $1 \mathrm{ml}$ with 10 $\mathrm{mM}$ potassium phosphate buffer ( $\mathrm{pH}$ 7.0) to which $1 \mathrm{ml}$ of $1 \mathrm{M}$ KI was added. The absorbance was measured at $390 \mathrm{~nm}$.

\subsection{Proline}

The free proline content was estimated according to Bates et al., (1973) [14]. Leaf tissue (500 mg) was homogenized with $3 \%$ sulfosalicylic acid in an ice bath. The homogenate was centrifuged at 10,000 rpm for 15 mins at $4^{\circ} \mathrm{C}$. The reaction mixture consisted of $2 \mathrm{ml}$ of filtrate, $2 \mathrm{ml}$ of acid-ninhydrin and $2 \mathrm{ml}$ of glacial acetic acid and incubated for $1 \mathrm{~h}$ at $100^{\circ} \mathrm{C}$. The tubes were immediately transferred onto an ice bath to terminate the reaction and the reaction mixture was extracted with $4 \mathrm{ml}$ of toluene. The chromophore-containing organic phase was separated from the hydrated phase and the absorbance was recorded at $520 \mathrm{~nm}$.

\subsection{Lipid Peroxidation}

The extent of lipid peroxidation was determined by measuring the MDA content formed by thiobarbituric acid reaction according to Heath and Packer (1968) [15], with suitable modification. $0.5 \mathrm{~g}$ of fresh tissue was homogenized with $5.0 \mathrm{ml}$ of $0.1 \%$ TCA containing $0.5 \%$ butylated hydroxytoluene and $1.0 \%$ PVP. The homogenate was centrifuged at $12,000 \times \mathrm{g}$ for $30 \mathrm{~min}$. The reaction mixture consisted of $2.0 \mathrm{ml}$ of the supernatant mixed with $2.0 \mathrm{ml}$ of the substrate ( $0.5 \%$ thiobarbituric acid and $20 \%$ TCA). The absorbance of supernatant was measured at $532 \mathrm{~nm}$ and the nonspecific absorbance at $600 \mathrm{~nm}$ was subtracted. The MDA content was calculated with an extinction coefficient of $155 \mathrm{mM}^{-1} \cdot \mathrm{cm}^{-1}$.

\section{Extraction of Enzymes}

The leaf samples were homogenized using pestle and mortar with pre-chilled $50 \mathrm{mM}$ sodium phosphate buffer (pH 7.0) containing $5 \mathrm{mM} \beta$-mercaptoethanol and 1mM EDTA. The homogenate was centrifuged at 10,000×g for $15 \mathrm{~min}$ at $4^{\circ} \mathrm{C}$. The supernatant collected was used as a source of enzymes. Soluble protein content was estimated according to Lowry et al. (1951) [16], using BSA as the standard.

\section{Assay of Antioxidant Enzymes}

\subsection{Guaiacol Peroxidase (POX, E.C. 1.11.1.7):(POX, E.C. 1.11.1.7)}

The activity of Guaiacol peroxidase was determined spectrophotometrically as described by Chance et al. (1955) [17]. The assay mixture contained $3.0 \mathrm{ml}$ of $50 \mathrm{mM}$ phosphate buffer ( $\mathrm{pH} 7.0$ ), $20 \mathrm{mM}$ guaiacol, $10 \mathrm{mM} \mathrm{H}_{2} \mathrm{O}_{2}$ and $100 \mu \mathrm{l}$ enzyme extract. The reaction was initiated by addition of $\mathrm{H}_{2} \mathrm{O}_{2}$. The tetraguaiacol formation was quantified at A470 $\mathrm{nm}\left(\varepsilon=26.6 \mathrm{mM}^{-1} \cdot \mathrm{cm}^{-1}\right)$. One unit of peroxidase is defined as the amount of enzyme required to convert $1 \mu \mathrm{mol}$ of $\mathrm{H}_{2} \mathrm{O}_{2} \min ^{-1}$ at $25^{\circ} \mathrm{C}$. 


\subsection{Catalase (CAT, E.C. 1.11.1.6)}

Activity of catalase was assayed according to the method of Aebi (1984) [18]. The oxidation of $\mathrm{H}_{2} \mathrm{O}_{2}$ was determined by following the decline in absorbance at $240 \mathrm{~nm}\left(\varepsilon=39.4 \mathrm{M}^{-1} \cdot \mathrm{cm}^{-1}\right)$. The reaction mixture consisted of $50 \mathrm{mM}$ sodium phosphate buffer ( $\mathrm{pH} 7.0$ ) containing $50 \mu \mathrm{l}$ of enzyme extract. The reaction was initiated with the addition of $10 \mathrm{mM} \mathrm{H}_{2} \mathrm{O}_{2}$ and its consumption was measured for 3 min. One unit of catalase activity is defined as the amount of enzyme required for oxidation of $1 \mu \mathrm{mol}$ of $\mathrm{H}_{2} \mathrm{O}_{2} \mathrm{~min}^{-1}$ under the assay conditions.

\subsection{Ascorbate Peroxidase (APX, E.C. 1.11.1.11)}

Ascorbate peroxidase activity was measured according to Allen (1995) [19]. In a $2.0 \mathrm{ml}$ reaction mixture containing $50 \mathrm{mM}$ HEPES buffer ( $\mathrm{pH} 7.0$ ), $1 \mathrm{mM}$ EDTA, $1 \mathrm{mM} \mathrm{H}_{2} \mathrm{O}_{2}, 0.5 \mathrm{mM}$ sodium ascorbate and $50 \mu \mathrm{l}$ of enzyme extract. Oxidation of ascorbate was followed by an increase in the absorption at $290 \mathrm{~nm}\left(\varepsilon=2.8 \mathrm{mM}^{-1} \cdot \mathrm{cm}^{-1}\right)$. One unit of APX is defined as the amount of enzyme needed to convert $1 \mu \mathrm{mol}$ of ascorbate min- 1 at $25^{\circ} \mathrm{C}$.

\subsection{Glutathione Reductase (GR, E.C. 1.6.4.2)}

GR activity was determined by measuring oxidation of NADPH at $340 \mathrm{~nm}\left(\varepsilon=6220 \mathrm{M}^{-1} \cdot \mathrm{cm}^{-1}\right)$ according to the method of Carlberg and Mannervik (1985) [20]. The assay mixture consisted of $50 \mathrm{mM}$ Tris-HCl buffer (pH 7.5), $3 \mathrm{mM} \mathrm{MgCl} 2,0.5 \mathrm{mM}$ GSSG, $0.2 \mathrm{mM}$ NADPH and $37 \mu$ of enzyme extract. The reaction was initiated by the addition of GSSG. One unit of activity is defined as the amount of glutathione reductase that catalyzes the oxidation of $1 \mu \mathrm{mol}$ of $\mathrm{NADPH} \mathrm{min}^{-1}$ under the assay conditions.

\section{Assay of Metabolic Enzymes}

\section{1. $\beta$-Amylase (AMY, E.C. 3.2.1.1)}

$\beta$-amylase activity was determined spectrophotometrically using the DNS method as described by Bernfield (1955) [21]. Reaction mixture taken consisted of $500 \mu \mathrm{l}$ of $2 \%$ starch solution in $50 \mathrm{mM}$ phosphate buffer (pH 7.0) and $500 \mu \mathrm{l}$ of enzyme extract. Each unit of activity is defined as the number of $\mu$ moles of maltose released per minute.

\subsection{Acid Phosphatase (AP, E.C. 3.1.3.2)}

Activity of AP against $\rho$-nitrophenol phosphate was determined by measuring the release of $\rho$-nitrophenol at 410 $\mathrm{nm}$ according to the method of Hoerling and Svensmark (1976) [22]. One unit of activity is defined as the amount of enzyme necessary to release $1 \mu$ moles of p-nitro phenol per minute.

\section{Statistical Analysis}

The experiments were performed using a randomized design. All data are expressed as means of triplicate experiments unless mentioned otherwise. The data were subjected to analysis of variance (ANOVA) using GraphPad Prism version 5.0 and the mean differences were compared by Lowest Standard Deviations (LSD) test. Each value represents the average of three replicates \pm standard error (SE) taking $\mathrm{P} \leq 0.05$ as significant.

\section{Results}

Salt stress in niger caused gradual reduction of Relative water content (RWC) in concentration and timedependent manner up to $400 \mathrm{mM} \mathrm{NaCl}$. However, beyond $400 \mathrm{mM}$, the trend appeared to show anomalous behavior. The highest reduction in RWC (56\%) was observed at $72 \mathrm{~h}$ with $400 \mathrm{mM} \mathrm{NaCl}$ (Table 1). The plant showed reduction in fresh weight with increasing $\mathrm{NaCl}$ concentration, with no significant change in dry weight relative to control. As salinity increased, the plants showed reduced number of leaf and cessation in the expansion of the leaf surface. Extended exposure to salinity caused wilting and deterioration of plants.

\subsection{Stress Markers}

Applied salt stress enhanced $\mathrm{H}_{2} \mathrm{O}_{2}$ production in concentration and time-dependent manner. Leaves of Niger 
Table 1. Effect of salt stress on RWC and mass of Niger (Guizotia abyssinica)*.

\begin{tabular}{|c|c|c|c|c|}
\hline \multirow{2}{*}{$\mathrm{NaCl}(\mathrm{mM})$} & \multirow{2}{*}{ Time (h) } & \multirow{2}{*}{$\begin{array}{c}\text { RWC (\%) } \\
\text { Leaf }\end{array}$} & \multicolumn{2}{|c|}{ Weight (g) } \\
\hline & & & Fresh & Dry \\
\hline \multirow{3}{*}{ Control } & 24 & $84.2 \pm 1.5$ & 0.0348 & 0.0021 \\
\hline & 48 & $84.5 \pm 1.7$ & 0.0432 & 0.0024 \\
\hline & 72 & $91.7 \pm 3.5$ & 0.0372 & 0.0027 \\
\hline \multirow{3}{*}{100} & 24 & $82.0 \pm 4.4$ & 0.0349 & 0.0029 \\
\hline & 48 & $87.4 \pm 2.1$ & 0.0446 & 0.0028 \\
\hline & 72 & $82.7 \pm 4.8$ & 0.0289 & 0.0028 \\
\hline \multirow{3}{*}{200} & 24 & $79.4 \pm 4.2$ & 0.0382 & 0.0026 \\
\hline & 48 & $69.8 \pm 1.8$ & 0.0404 & 0.0026 \\
\hline & 72 & $59.5 \pm 8.4$ & 0.0174 & 0.0023 \\
\hline \multirow{3}{*}{300} & 24 & $74.7 \pm 5.2$ & 0.0326 & 0.0025 \\
\hline & 48 & $73.7 \pm 1.7$ & 0.0389 & 0.0031 \\
\hline & 72 & $59.0 \pm 5.8$ & 0.0172 & 0.0030 \\
\hline \multirow{3}{*}{400} & 24 & $82.3 \pm 1.9$ & 0.0386 & 0.0030 \\
\hline & 48 & $77.9 \pm 5.5$ & 0.0365 & 0.0031 \\
\hline & 72 & $42.4 \pm 7.9$ & 0.0131 & 0.0026 \\
\hline \multirow{3}{*}{500} & 24 & $73.9 \pm 5.5$ & 0.0347 & 0.0030 \\
\hline & 48 & $77.7 \pm 1.7$ & 0.0302 & 0.0030 \\
\hline & 72 & $61.0 \pm 4.6$ & 0.0192 & 0.0027 \\
\hline
\end{tabular}

\footnotetext{
*Individual seedlings of Niger were subjected to salt stress for 24 - $72 \mathrm{~h}$ with $\mathrm{NaCl}(100-500 \mathrm{mM})$ and analyzed for determination of RWC and weight. Three seedlings from each treatment were chosen for determination of morphological parameters. Values for FW and DW are \pm SE $( \pm 0.001)$.
}

showed up to 3-fold increase in the levels of $\mathrm{H}_{2} \mathrm{O}_{2}$ at $300 \mathrm{mM} \mathrm{NaCl}$ exposed for 48 and $72 \mathrm{~h}$. Salt stress also caused increase in ASC levels in concentration and time-dependent manner, with concentration producing profound effect. Reduced glutathione levels in salt stressed leaves of Niger were elevated in a concentration-dependent manner up to $300 \mathrm{mM}$. However, the effect was not pronounced beyond $48 \mathrm{~h}$ of exposure. The (MDA) content in salinity stressed leaves did not show any alteration, except a marginal concentration-dependent increase at $72 \mathrm{~h}$. Levels of osmoprotectant; proline in salt stressed Niger exhibited $\sim 2$ fold increase, relative to control independent of time of exposure and concentration of $\mathrm{NaCl}$ (Table 2).

\subsection{Antioxidant Enzymes}

Guaiacol specific POX levels showed a concentration-dependent elevation up to $300 \mathrm{mM} \mathrm{NaCl}$, and declined gradually beyond $300 \mathrm{mM}$ (Figure 1). APX also showed a time and concentration-dependent increase between $200-400 \mathrm{mM}$ of $\mathrm{NaCl}$ and declined beyond $400 \mathrm{mM}$ (Figure 2). CAT activity exhibited a progressive decrease with time and concentration of $\mathrm{NaCl}$. The decline was more pronounced at $48 \mathrm{~h}$ of stress (Figure 3). GR levels showed a concentration and time-dependent elevation up to $400 \mathrm{mM} \mathrm{NaCl}$, but declined at $500 \mathrm{mM}$ (Figure 4). Metabolic enzymes $\beta$-amylase and acid phosphatase did not exhibit any specific pattern, except a raise in their activities during $24 \mathrm{~h}$ of exposure to salinity (Figure 5, Figure 6). 


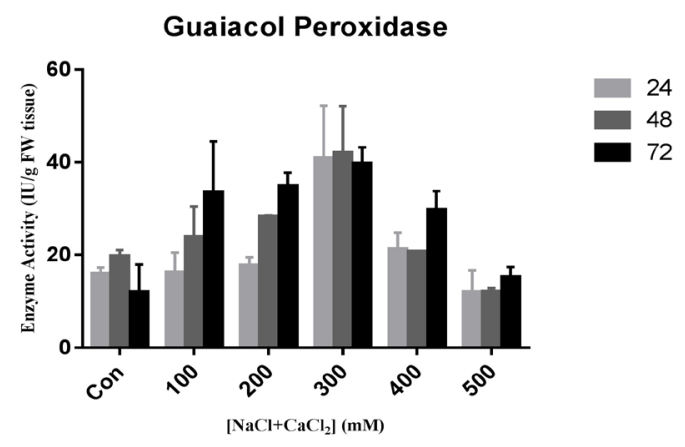

Figure 1. Effect of salt stress on GPX activity in leaves of Niger. Values are mean $\pm \mathrm{SE}(\mathrm{P} \leq 0.05)$, obtained from three replicates.

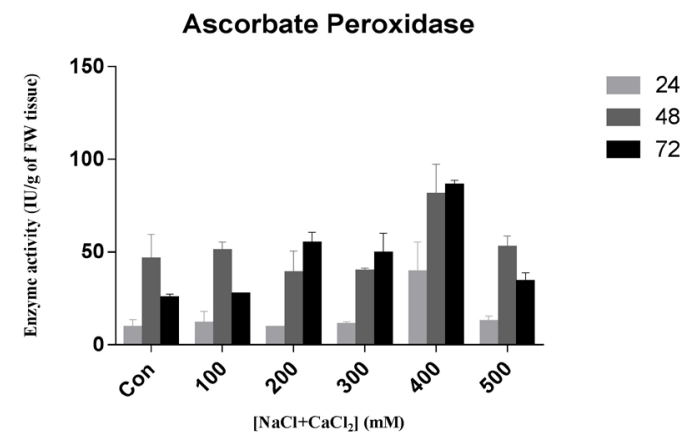

Figure 2. Effect of salt stress on APX activity in leaves of Niger. Values are mean $\pm S E(P \leq 0.05)$, obtained from three replicates.

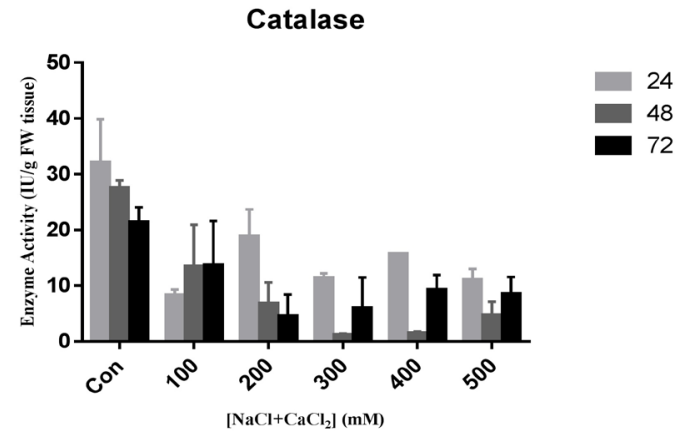

Figure 3. Effect of salt stress on CAT activity in leaves of Niger. Values are mean $\pm \mathrm{SE}(\mathrm{P} \leq 0.05)$, obtained from three replicates.

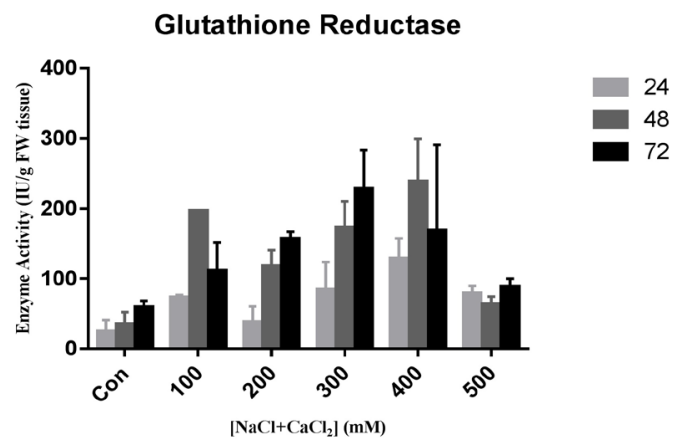

Figure 4. Effect of salt stress on GR activity in leaves of Niger. Values are mean $\pm \mathrm{SE}(\mathrm{P} \leq 0.05)$, obtained from three replicates. 


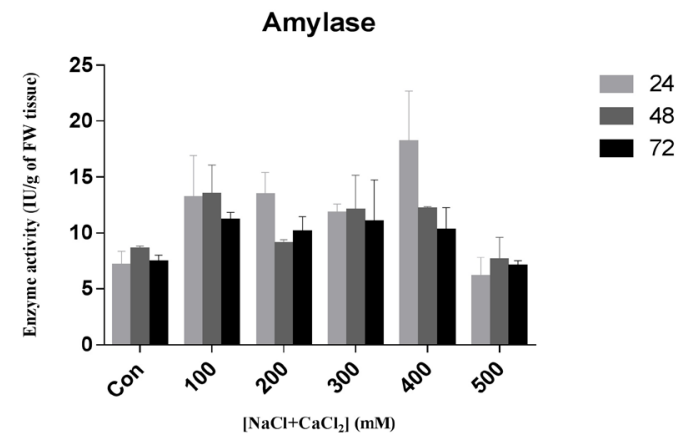

Figure 5. Effect of salt stress on AMY activity in leaves of Niger. Values are mean $\pm \mathrm{SE}(\mathrm{P} \leq 0.05)$, obtained from three replicates.

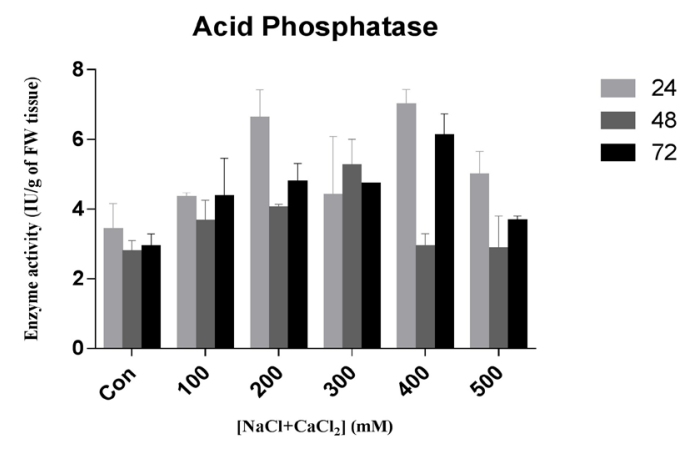

Figure 6. Effect of salt stress on AP activity in leaves of Niger. Values are mean $\pm S E(P \leq 0.05)$, obtained from three replicates.

Table 2. Levels of stress markers in leaves of Niger (Guizotia abyssinica) subjected to salt stress* .

\begin{tabular}{|c|c|c|c|c|c|c|c|c|}
\hline \multirow{2}{*}{ Tissue } & \multirow{2}{*}{ Time } & \multirow{2}{*}{$\begin{array}{l}\text { Stress } \\
\text { markers }\end{array}$} & \multicolumn{6}{|c|}{ Concentration of $\mathrm{NaCl}$} \\
\hline & & & Control & $100 \mathrm{mM}$ & $200 \mathrm{mM}$ & $300 \mathrm{mM}$ & $400 \mathrm{mM}$ & $500 \mathrm{mM}$ \\
\hline & & $\mathrm{H}_{2} \mathrm{O}_{2}{ }^{\mathrm{a}}$ & $20.7 \pm 0.77$ & $23.99 \pm 1.0$ & $29.23 \pm 0.73$ & $15.15 \pm 0.52$ & $17.16 \pm 0.82$ & $16.32 \pm 0.88$ \\
\hline & & Proline $^{b}$ & $0.48 \pm 0.01$ & $1.83 \pm 0.01$ & $1.56 \pm 0.05$ & $1.23 \pm 0.03$ & $1.70 \pm 0.02$ & $0.628 \pm 0.007$ \\
\hline & $24 \mathrm{~h}$ & $\mathrm{MDA}^{\mathrm{c}}$ & $2.59 \pm 0.28$ & $2.36 \pm 0.30$ & $2.103 \pm 0.24$ & $2.7 \pm 0.11$ & $1.9 \pm 0.18$ & $2.8 \pm 0.58$ \\
\hline & & $\mathrm{GSH}^{\mathrm{a}}$ & $70.07 \pm 2.59$ & $123.97 \pm 7.54$ & $63.7 \pm 4.25$ & $205.26 \pm 5.8$ & $107.31 \pm 3.36$ & $139.4 \pm 6.25$ \\
\hline & & Ascorbate $^{b}$ & $26.32 \pm 1.33$ & $33.48 \pm 1.23$ & $41.26 \pm 0.97$ & $46.2 \pm 1.04$ & $45.4 \pm 2.42$ & $56.79 \pm 1.65$ \\
\hline & & $\mathrm{H}_{2} \mathrm{O}_{2}{ }^{\mathrm{a}}$ & $17.65 \pm 0.64$ & $20.03 \pm 1.0$ & $71.24 \pm 3.56$ & $133.66 \pm 4.8$ & $42.56 \pm 1.19$ & $48.52 \pm 1.28$ \\
\hline & & Proline $^{b}$ & $0.73 \pm 0.06$ & $1.60 \pm 0.04$ & $1.57 \pm 0.02$ & $1.88 \pm 0.007$ & $1.71 \pm 0.04$ & $1.03 \pm 0.03$ \\
\hline \multirow[t]{8}{*}{ Leaf } & $48 \mathrm{~h}$ & $\mathrm{MDA}^{\mathrm{c}}$ & $2.45 \pm 0.14$ & $2.2 \pm 0.33$ & $3.8 \pm 0.21$ & $3.11 \pm 0.36$ & $3.51 \pm 0.05$ & $2.93 \pm 0.28$ \\
\hline & & $\mathrm{GSH}^{\mathrm{a}}$ & $127.64 \pm 8.72$ & $153.61 \pm 2.9$ & $152.14 \pm 7.01$ & $190.12 \pm 4.25$ & $116.86 \pm 5.54$ & $227.36 \pm 7.2$ \\
\hline & & Ascorbate $^{b}$ & $28.33 \pm 0.81$ & $45.54 \pm 1.92$ & $59.44 \pm 2.99$ & $67.36 \pm 0.94$ & $79.02 \pm 1.46$ & $84.42 \pm 0.85$ \\
\hline & & $\mathrm{H}_{2} \mathrm{O}_{2}{ }^{\mathrm{a}}$ & $48.53 \pm 1.74$ & $72.32 \pm 6.41$ & $133.04 \pm 2.92$ & $160.93 \pm 2.72$ & $101.92 \pm 10.03$ & $142.18 \pm 2.46$ \\
\hline & & Proline $^{b}$ & $0.623 \pm 0.02$ & $1.84 \pm 0.002$ & $1.85 \pm 0.006$ & $1.83 \pm 0.021$ & $1.79 \pm 0.008$ & $1.12 \pm 0.021$ \\
\hline & $72 \mathrm{~h}$ & $\mathrm{MDA}^{\mathrm{c}}$ & $3.39 \pm 0.125$ & $9.058 \pm 1.31$ & $5.58 \pm 0.94$ & $5.75 \pm 0.37$ & $6.58 \pm 0.36$ & $7.17 \pm 0.55$ \\
\hline & & $\mathrm{GSH}^{\mathrm{a}}$ & $109.76 \pm 7.47$ & $156.31 \pm 4.5$ & $78.4 \pm 1.76$ & $62.47 \pm 4.04$ & $82.28 \pm 4.24$ & $80.36 \pm 4.9$ \\
\hline & & Ascorbate $^{b}$ & $32.35 \pm 1.38$ & $38.7 \pm 0.72$ & $47.7 \pm 2.31$ & $59.26 \pm 2.78$ & $71.55 \pm 0.41$ & $81.81 \pm 1.38$ \\
\hline
\end{tabular}

\footnotetext{
${ }^{*} \mathrm{a} \mu \mathrm{g} / \mathrm{g}$ fresh weight tissue; ${ }^{\mathrm{b}} \mathrm{mg} / \mathrm{g}$ fresh weight tissue; ${ }^{\mathrm{c}} \mathrm{m}$ moles/g fresh weight tissue.
} 


\section{Discussion}

Adverse effects of salinity in plants include reduction in overall growth and productivity due to perturbation of various physiological and biochemical parameters. Conveniently, a number of such parameters have served as markers of stress response, as well as, indicators of the severity of stress. Reduction in fresh and dry weight (Table 1), leaf surface area and number of leaves in Niger suggested significant negative influence of salt concentration beyond $400 \mathrm{mM}$ up to $72 \mathrm{~h}$ of exposure. The extensive damage observed beyond $400 \mathrm{mM}$ at extended exposure could be due to reverse osmosis, wherein osmolarity of the medium surpasses that of the plant sap. The growth reduction under stress is attributed to reduced cell volume, turgor and concomitant reduction in cell elongation [23], as observed in faba bean [24].

When challenged by stress, plant system respond by invoking signaling system, which induce expression of various genes specific to the applied stress. One of the early changes in plants metabolism and physiology during abiotic stress such as salinity is, production of ROS; $\mathrm{O}_{2}^{-}, \mathrm{H}_{2} \mathrm{O}_{2},{ }^{1} \mathrm{O}_{2}$ and $\mathrm{OH}^{-}$. This ROS production is attributed to metabolic utilization of reducing power and imbalance in electron transport [25]. One of the earliest stress signaling components appears to be $\mathrm{H}_{2} \mathrm{O}_{2}$, a stable ROS intermediate, produced by progressive reduction in PS-II and $\beta$-oxidation of lipids during abiotic stress [26]. Progressive elevation of $\mathrm{H}_{2} \mathrm{O}_{2}$ in salt stressed Niger suggested imposition of greater degree of stress with increasing concentration of $\mathrm{NaCl}$ and time of exposure (Table 2). Apart from serving as signaling molecules, elevated levels of $\mathrm{H}_{2} \mathrm{O}_{2}$ are found to accelerate HaberWeiss reaction forming $\mathrm{OH}^{-}$, which in turn, causes lipid peroxidation [27]. Although $\mathrm{H}_{2} \mathrm{O}_{2}$ levels peaked at 300 $\mathrm{mM}$ during $72 \mathrm{~h}$, there was no corresponding increase in MDA (Table 2), probably due to onset/reinforcement of antioxidant systems [28] as suggested for groundnut [29] and soybean [30] under salt stress.

Abiotic stresses have been shown to disturb redox homeostasis of ASC and GSH. As a water soluble antioxidant, ASC serves as a ROS scavenger during stressed conditions. Complementing the functions of ASC is reduced GSH, contributing to a formidable antioxidant system in plants under abiotic stress [31]. Reduced GSH primarily donates electrons for reduction of ASC (Asada-Halliwell cycle) and also, acts as a potent scavenger of ROS [32]. This interrelationship between ASC and GSH in Niger was evident from the parallel increase in ASC and GSH levels over the time and concentration regimes (Table 2). However, the ASC production seems to be more efficient up to $500 \mathrm{mM} \mathrm{NaCl}$ while GSH production declined beyond $400 \mathrm{mM} \mathrm{NaCl}$. Nevertheless, the pattern of these antioxidants suggested the operation of ASC-GSH cycle, which could partially contribute to stress tolerance exhibited, at least, up to $300 \mathrm{mM} \mathrm{NaCl}$. Pisum sativum subjected to cadmium stress has been shown to exhibit similar response [33].

Salinity induced adjustment in osmolarity of plants involve accumulation of osmoprotectants such as proline, glycine betaine and sugars [34]. Proline, as a compatible solute and enzyme protectant stabilizes structures of macromolecules and organelles [35]. Observed enhancement of proline levels suggested an efficient osmotic adjustment in niger (Table 2), which is in agreement with observations made in salt stressed tobacco [36], sorghum [37] and Sesuvium portulacastrum [38].

Enzymatic antioxidant system in plants includes SOD, CAT, GR and POX. These enzymes are shown to be induced or up regulated during oxidative stress resulting from abiotic stresses. ROS detoxification, particularly of $\mathrm{H}_{2} \mathrm{O}_{2}$ is due to continued action of POX and CAT. Salt stress induced ROS $\left(\mathrm{H}_{2} \mathrm{O}_{2}\right)$ in Niger seem to be primarily detoxified by POXs, as measured by GPOX and APX. GPOX, as a proven ROS quencher, is also associated with metabolism of plant hormones such as ethylene, indole acetic acid (IAA), and processes like cell wall lignification and wound healing [39]. Progressive elevation in GPOX up to $300 \mathrm{mM} \mathrm{NaCl}$ in parallel to $\mathrm{H}_{2} \mathrm{O}_{2}$ levels appears to contribute to salt tolerance in niger (Figure 1). The observed enzyme levels in Niger were in consonance with those of drought stressed Hyacinth bean [40] and varieties of wheat [41]. ROS scavenging by APX involves reduction of $\mathrm{H}_{2} \mathrm{O}_{2}$ using ASC as electron donor. Time and concentration-dependent increase in levels of APX between $200 \mathrm{mM}$ to $400 \mathrm{mM}$ (Figure 2) was in consonance with salt-tolerant wild tomato [42] and drought stressed Festuca arundinacea genotypes [43]. Unlike POX, CAT levels continued to decline with increasing concentration of $\mathrm{NaCl}$ and extended time of exposure (Figure 3), suggesting the primacy of POX in $\mathrm{H}_{2} \mathrm{O}_{2}$ detoxification. These observations in Niger are in good agreement with salt and drought stressed liquorice [44], heavy metal stressed sunflower [45] and salt stressed Jatropha curcas L. [46].

Among antioxidant enzymes, GR plays a crucial role in regeneration of reduced glutathione, which in turn, can be a reducing equivalent donor for reduction of dehydroascorbate. Concentration dependent elevation of GR under salinity stress up to $400 \mathrm{mM} \mathrm{NaCl}$ (Figure 4) in niger correlated with reduced GSH levels, thus contri- 
buting to efficient operation of GSH-ASC cycle. Similar increase in GR activity under salt stress was previously reported for barley [28] and cucumber [47].

Structural integrity of macromolecules and cell turgidity are critically maintained during applied stresses by various molecules including sugars. Mobilization of starch during stress appears to be a common mechanism to protect cellular integrity. $\beta$-amylases have been shown to contribute to osmotic adjustment and turgidity [48]. Enhanced levels of $\beta$-amylase in presence of $\mathrm{NaCl}$ up to $400 \mathrm{mM}$ suggested an efficient adjustment in turgor and valuable contribution of this enzyme in niger plant during initial $24 \mathrm{~h}$ of exposure (Figure 5). Similar results have been reported in cucumber under water stress [49] and Triticum aestivum under salt stress [50].

In numerous plant species, on account of salinity stress, AP activity typically increases under phosphorous (Pi) deficiency. Elevated levels of AP activity in leaves of Niger was seen during the early period of applied stress (Figure 6) indicating a possible contribution to phosphorous remobilization, as seen in hyacinth bean cultivars subjected to drought stress [40].

\section{Conclusion}

The antioxidant system invoked by Niger under salt stress comprised enzymatic components, POX, APX and GR and non-enzymatic components, GSH and ASC. Levels of GSH, ASC and GR indicated efficient operation of ASC-GSH cycle under stress. Salt induced osmotic stress also seems to be countered by increased production of the osmolyte, proline. Further, metabolic enzymes $\beta$-amylase and acid phosphatase were found to contribute to salt tolerance albeit over short period. These prevailing biochemical events thus make Niger tolerant to salinity stress up to $300 \mathrm{mM}$.

\section{Acknowledgements}

H. Kavya Naik acknowledges the Department of Science and Technology, Government of India for financial support vide reference No. SR/WOS-A/LS-1167/2014 (G).

\section{References}

[1] Pooja, S. and Rajesh, K. (2015) Soil Salinity: A Serious Environmental Issue and Plant Growth Promoting Bacteria as One of the Tools for Its Alleviation. Saudi Journal of Biological Sciences, 22, 123-131. http://dx.doi.org/10.1016/j.sjbs.2014.12.001

[2] Munns, R. and Tester, M. (2008) Mechanisms of Salinity Tolerance. Annual Review of Plant Biology, 59, $651-681$. http://dx.doi.org/10.1146/annurev.arplant.59.032607.092911

[3] Wang, H.-M., Xiao, X.-R., Yang, M.-Y., Gao, Z.-L., Zang, J., Fu, X.-M. and Chen, Y.-H. (2014) Effects of Salt Stress on Antioxidant Defense System in the Root of Kandelia candel. Botanical Studies, 55, 57. http://dx.doi.org/10.1186/s40529-014-0057-3

[4] Myrene, R. and Devaraj, V.R. (2010) Biochemical Responses of Hyacinth bean (Lablab purpureus) to Salinity Stress. Acta Physiologiae Plantarum, 32, 341-353. http://dx.doi.org/10.1007/s11738-009-0412-2

[5] Halliwell, B. and Guteridge J.M.C. (1989) Protection against Oxidants in Biological Systems: The Superoxide Theory of Oxygen Toxicity. Clarendon Press, Oxford, 86-179.

[6] Zhang, L., Ma, H., Chem, T., Pen, J., Yu, S., et al. (2014) Morphological and Physiological Responses of Cotton (Gossypium hirsutum L.) Plants to Salinity. PLoS ONE, 9, e112807. http://dx.doi.org/10.1371/journal.pone.0112807

[7] Rakesh, S., Meeta, S. and Arif, A.K. (2009) Studies on Guizotia abyssinica L. Oil: Biodiesel Synthesis and Process Optimization. Bioresource Technology, 100, 4187-4192. http://dx.doi.org/10.1016/j.biortech.2009.03.072

[8] Ghane, S.G. and Nikam, T.D. (2014) Growth, Physiological, and Biochemical Responses in Relation to Salinity Tolerance for In Vitro Selection in Oil Seed Crop Guizotia abyssinica Cass. Journal Crop Science and Biotech Technology, 17, 11-20. http://dx.doi.org/10.1007/s12892-013-0084-8

[9] Allen, M.M. (1968) Simple Conditions for Growth of Unicellular Blue-Green Algae on Plates. Journal of Phycology, 4, 1-4. http://dx.doi.org/10.1111/j.1529-8817.1968.tb04667.x

[10] Turner, N.C. and Kramer, P.J. (Ed) (1980) Adaptation of Plant to Water and High Temperature Stress. Wiley Interscience Pub, New York, 207-230.

[11] Sadasivam, S. and Manickam, A. (1997) Vitamins. In: Sadasivam, S. and Manickam, A., Eds., Biochemical Methods, 2nd Edition, New Age International (P) Ltd., New Delhi, 185-186.

[12] Beutler, E., Duron, O. and Kelly, B.M. (1963) Improved Method for Determination of Blood Glutathione. Journal of 
Laboratory and Clinical Medicine, 61, 882-888.

[13] Velikova, V., Yordanov, I. and Edreva, A. (2000) Oxidative Stress and Some Antioxidant System in Acid Rain Treated Bean Plants: Protective Role of Exogenous Polyamines. Plant Science, 151, 59-66. http://dx.doi.org/10.1016/S0168-9452(99)00197-1

[14] Bates, L.S., Waldren, R.P. and Teare, I.D. (1973) Rapid Determination of Free Proline for Water-Stress Studies. Plant and Soil, 39, 205-207. http://dx.doi.org/10.1007/BF00018060

[15] Heath, R.L. and Packer, L. (1968) Photoperoxidation in Isolated Chloroplasts: I. Kinetics and Stoichiometry of Fatty Acid Peroxidation. Archives of Biochemistry and Biophysics, 125, 189-198. http://dx.doi.org/10.1016/0003-9861(68)90654-1

[16] Lowry, O.H., Rosebrough, N.J., Farr, A.R. and Randoll, R.J. (1951) Protein Measurement with Folin Phenol Reagent. The Journal of Biological Chemistry, 193, 265-275.

[17] Chance, B. and Maehly, A.C. (1955) Assays of Catalases and Peroxidases. Methods in Enzymology, 2, 764-775. http://dx.doi.org/10.1016/S0076-6879(55)02300-8

[18] Aebi, H. (1984) Catalase in Vitro. Methods in Enzymology, 105, 121-126. http://dx.doi.org/10.1016/S0076-6879(84)05016-3

[19] Allen, M.M. (1968) Simple Conditions for Growth of Unicellular Blue-Green Algae on Plates. Journal of Phycology, 4, 1-4. http://dx.doi.org/10.1111/j.1529-8817.1968.tb04667.x

[20] Carlberg, I. and Mannervik, B. (1985) Glutathione Reductase. Methods in Enzymology, 113, 484-490. http://dx.doi.org/10.1016/S0076-6879(85)13062-4

[21] Bernfeld, P. (1955) Amylase $\alpha$ and $\beta$. Methods in Enzymology, 1, 149-151. http://dx.doi.org/10.1016/0076-6879(55)01021-5

[22] Hoerling, N. and Svensmark, O. (1976) Carboxyl Esterase with Different Substrate Specificity in Human Brain Extracts. Journal of Neurochemistry, 27, 523-528. http://dx.doi.org/10.1111/j.1471-4159.1976.tb12277.x

[23] Boyer, J.S. (1988) Cell Enlargement and Growth-Induced Water Potentials. Physiologia Plantarum, 73, 311-316. http://dx.doi.org/10.1111/j.1399-3054.1988.tb00603.x

[24] Tavakkoli, E., Rengasamy, P. and McDonald, G.K. (2010) High Concentration of $\mathrm{Na}^{+}$and $\mathrm{Cl}^{-}$Ions in Soil Solution Have Simultaneous Detrimental Effects on Growth of Faba Bean under Salinity Stress. Journal of Experimental Botany, 61, 4449-4459. http://dx.doi.org/10.1093/jxb/erq251

[25] Heyno, E., Mary, V., Schopfer, P. and Krieger-Liszkay, A. (2011) Oxygen Activation at the Plasma Membrane: Relation between Superoxide and Hydroxyl Radical Production by isolated Membranes. Planta, 234, 35-45. http://dx.doi.org/10.1007/s00425-011-1379-y

[26] Gill, S.S. and Tuteja, N. (2010) Reactive Oxygen Species and Antioxidant Machinery in Abiotic Stress Tolerance in Crop Plants. Plant Physiology and Biochemistry, 48, 909-930. http://dx.doi.org/10.1016/j.plaphy.2010.08.016

[27] Loggini, B., Scartazza, A., Brugnoli, E. and Navari-Izzo, F. (1999) Antioxidative Defense System, Pigment Composition, and Photosynthetic Efficiency in Two Wheat Cultivars Subjected to Drought. Plant Physiology, 119, 1091-1100. http://dx.doi.org/10.1104/pp.119.3.1091

[28] Liang, Y.C., Chen, Q., Liu, Q., Zhang, W.H. and Ding, R.X. (2003) Exogenous Silicon (Si) Increases Antioxidant Enzyme Activity and Reduces Lipid Peroxidation in Roots of Salt-Stressed Barley (Hordeum vulgare L.). Journal of Plant Physiology, 160, 1157-1164. http://dx.doi.org/10.1078/0176-1617-01065

[29] Amruta, S., Ashutosh, V., Ritu, M. and Pushpa, R. (2014) Changes in Activity of Enzymes Involved in Maintaining ROS in Ground Nut during Salt Stress. Research Journal of Agriculture and Forestry Sciences, 2, 1-6.

[30] Weisany, W., Sohrabi, Y., Heidari, G., Siosemardeh, A. and Ghassemi-Golezani, K. (2012) Changes in Antioxidant Enzymes Activity and Plant Performance by Salinity Stress and Zinc Application in Soybean (Glycine max L.). Plant Omics, 5, 60-67

[31] Asada, K. (2006) Production and Scavenging of Reactive Oxygen Species in Chloroplasts and Their Functions. Plant Physiology, 141, 391-396. http://dx.doi.org/10.1104/pp.106.082040

[32] Foyer, C.H. and Halliwell, B. (1976) The Presence of Glutathione and Glutathione Reductase in Chloroplasts: A Proposed Role in Ascorbic Acid Metabolism. Planta, 133, 21-25. http://dx.doi.org/10.1007/BF00386001

[33] Metwally, A., Safronova, V.I., Belimov, A.A. and Dietz, K.-J. (2005) Genotypic Variation of the Response to Cadmium Toxicity in Pisium sativum. Journal of Experimental Botany, 56, 167-178.

[34] Deinlein, U., Stephan, A.B., Horie, T., Luo, W., Xu, G.H. and Schroeder, J.I. (2014) Plant Stress Tolerance Mechanism. Trends in Plant Science, 19, 371-379. http://dx.doi.org/10.1016/j.tplants.2014.02.001

[35] Hayat, S., Hayat, Q., Alyemeni, M.N., Wani, A.S., Pichtel, J. and Ahamad, A. (2012) Role of Proline under Changing 
Environments: A Review. Plant Signaling and Behavior, 7, 1456-1466. http://dx.doi.org/10.4161/psb.21949

[36] Çelik, Ö. and Atak, C. (2012) The Effect of Salt Stress on Antioxidative Enzymes and Proline Content of Two Turkish Tobacco Varieties. Turkish Journal of Biology, 36, 339-356.

[37] Kahrizi, S., Sedghi, M. and Sofalian, O. (2012) Effect of Salt Stress on Proline and Activity of Antioxidant Enzymes in Tendurum Wheat Cultivars. Annals of Biological Research, 3, 3870-3874.

[38] Rajaravindran, M. and Natarajan, S. (2012) Effects of Salinity Stress on Growth and Biochemical Constituents of the Halophyte Sesuvium portulacastrum. International Journal of Research in Biological Sciences, 2, 18-25.

[39] Mika, A. and Lüthje, S. (2003) Properties of Guaiacol Peroxidase Activities Isolated from Corn Root Plasma Membranes. Plant Physiology, 132, 1489-1498. http://dx.doi.org/10.1104/pp.103.020396

[40] Kokila, S., Myrene, R.D. and Devaraj, V.R. (2014) Response of Lablab purpureus (Hycianth Bean) Cultivars to Drought Stress. Asian Journal of Plant Science and Research, 4, 48-55.

[41] Usha, C. and Bhumika, P. (2012) Oxidative Stress in Five Wheat Varieties (Triticum aestivum L.) Exposed to Water Stress and Study of Their Antioxidant Enzyme Defense System, Water Stress Responsive Metabolites and $\mathrm{H}_{2} \mathrm{O}_{2}$ Accumulation. Brazilian Journal of Plant Physiology, 24, 117-130. http://dx.doi.org/10.1590/S1677-04202012000200005

[42] Shalata, A., Mittova, V., Volokita, M., Guy, M. and Tal, M. (2001) Response of the Cultivated Tomato and Its Wild Salt-Tolerant Relative Lycopersicon pennellii to Salt-Dependent Oxidative Stress: The Root Antioxidative System. Physiologia Plantarum, 112, 487-494. http://dx.doi.org/10.1034/j.1399-3054.2001.1120405.x

[43] Sarmast, M.K., Salehi, H. and Niazi, A. (2015) Biochemical Differences Underlie Varying Drought Tolerance in Four Festuca arundinacea Schreb. Genotypes Subjected to Short Waster Scarcity. Acta Physiologiae Plantarum, 37, 192. http://dx.doi.org/10.1007/s11738-015-1942-4

[44] Pan, Y., Wu, L.J. and Yu, Z.L. (2006) Effect of Salt and Drought Stress on Antioxidant Enzymes Activities and SOD Isoenzymes of Liquorice (Glycyrrhiza uralensis Fisch). Plant Growth Regulation, 49, 157-165. http://dx.doi.org/10.1007/s10725-006-9101-y

[45] Gallego, S.M., Benavídes, M.P. and Tomaro, M.L. (1996) Effect of Heavy Metal Ion Excess on Sunflower Leaves: Evidence for Involvement of Oxidative Stress. Plant Science, 121, 151-159. http://dx.doi.org/10.1016/S0168-9452(96)04528-1

[46] de Oliveira, M.L., et al. (2012) Photosynthesis and Antioxidant Activity in Jatropha curcas L. under Salt Stress. Brazilian Journal of Plant Physiology, 24, 55-67. http://dx.doi.org/10.1590/S1677-04202012000100008

[47] Lechno, S., Zamski, E. and Tel-Or, E. (1997) Salt Stress-Induced Responses in Cucumber Plants. Journal of Plant Physiology, 150, 206-211. http://dx.doi.org/10.1016/S0176-1617(97)80204-0

[48] Kotting, O., Kossmann, J., Zeeman, S.C. and Lloyd, J.R. (2010) Regulation of Starch Metabolism: The Age of Enlightenment. Current Opinion in Plant Biology, 13, 321-329. http://dx.doi.org/10.1016/j.pbi.2010.01.003

[49] Todaka, D., Matsushima, H. and Morohashi, Y. (2000) Water Stress Enhances $\beta$-Amylase Activity in Cucumber Cotyledon. Journal of Experimental Botany, 51, 739-745. http://dx.doi.org/10.1093/jexbot/51.345.739

[50] Chiraz, C.H., Afef, H.N., Donia, B. and Houda, G. (2013) Variations in $\alpha$-, $\beta$-Amylase and $\alpha$-Glycosidase Activities in Two Genotypes of Wheat under NaCl Salinity Stress. African Journal of Agricultural Research, 8, 2038-2043. 